\title{
Detection and confirmation of hispolon in the mushroom Phellinus linteus
}

\author{
Padungrat Toopmuang $^{\mathrm{a}}$, Chutarat Khamchum ${ }^{\mathrm{a}, \mathrm{b}}$, Vittaya Punsuvon ${ }^{\mathrm{a}, \mathrm{b}, \mathrm{c}, *}$ \\ a Department of Chemistry, Faculty of Science, Kasetsart University, Bangkok 10900 Thailand \\ b Centre of Excellent-Oil Palm, Kasetsart University, Bangkok 10900 Thailand \\ c Centre of Advanced Studied in Tropical Natural Resource, NRU-KU, Kasetsart University, \\ Bangkok 10900 Thailand
}

*Corresponding author, e-mail: fscivit@ku.ac.th

\begin{abstract}
Phellinus linteus (PL), a mushroom known as krathin phiman in Thai, has been used as a traditional medicine in the treatment of various cancers. Hispolon obtained from PL ethanol extracts is a promising anti-cancer compound. In this study, ethanol concentration and extraction time were varied for a soxhlet extraction. The content of hispolon in a crude extract was determined by high performance liquid chromatography with a UV detector. The presence of hispolon in the crude extract was demonstrated by liquid chromatography-tandem mass spectrometry (LC-MS/MS) with daughter ion scanned mode. The results showed that both hispolon and Thai PL have a similar parent ion at $m / z 218.91$ and daughter ions at $m / z 176,160,135$.
\end{abstract}

KEYWORDS: medicinal mushroom, agaricales, soxhlet extraction, phenolic compound

\section{INTRODUCTION}

In recent years, the development of new anti-cancer drugs is a key issue for cancer chemotherapy, because cancer cells resistant to current chemotherapy can dominate the cell population and cause mortality ${ }^{1}$. Furthermore, the traditional folk herbal medicine as an alternative cancer therapy has attracted substantial attention due to its low toxicity and costs. Phellinus linteus (PL) is a mushroom commonly called krathin phiman in Thailand or sangwhang in Taiwan (Fig. 1). It is found abundantly in the northern region of Thailand, as a solid shape like wood. It takes more than one hundred years to expand its diameter to $20-30 \mathrm{~cm}$. The price of PL is very high as it can be used as raw material for medicine production. At the moment, PL is scarcely found because it has been exported for more than ten years.

$P$. linteus is popular in oriental countries and has been traditionally used as food and medicine. It contains many bioactive compounds and is believed to improve health and to prevent and remedy various diseases such as gastroenteric disorders, lymphatic diseases, and cancers ${ }^{2}$. Many researchers reported ${ }^{3}$ that hispolon, a phenolic compound isolated from PL, has anti-inflammatory, antiproliferative, and antimetastatic effects.

Hispolon, a yellow pigment first found in Inono-

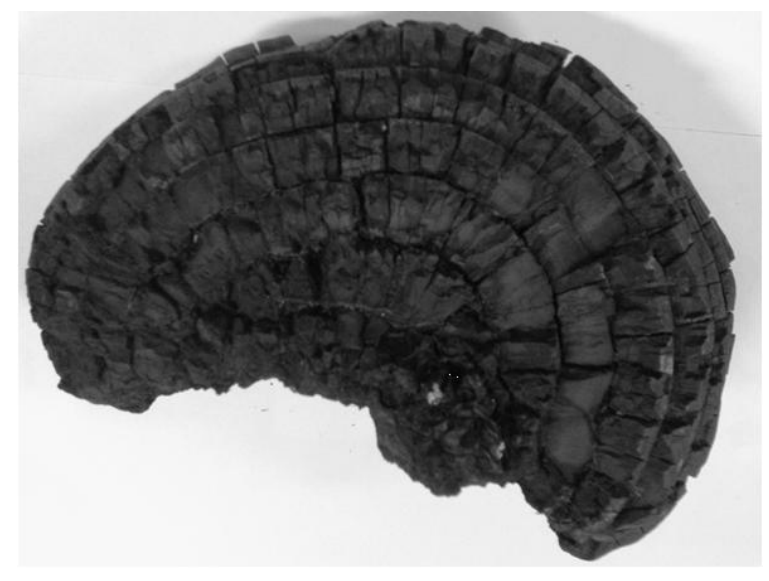

Fig. 1 Phellinus linteus.

tus hispidus in $1996^{4}$, was isolated from the P. igniarius $^{5}$. It has been reported to induce apoptosis in human epidermoid KB cells and to have antiviral activities ${ }^{6}$. Hispolon also inhibits chemiluminescence response of human mononuclear cells and suppress nitrogen-induced proliferation of spleen lymphocytes of mice ${ }^{4}$. The structural formula of hispolon is shown in Fig. 2.

Hispolon was extracted from mushroom with methanol, ethanol, or ethyl acetate. The crude extract was further analysed for hispolon content by high 


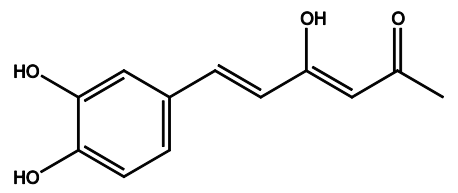

Fig. 2 Chemical structure of hispolon.

performance liquid chromatography (HPLC) with UV detector. A review of the analysis is as follows. The quantification and confirmation of hispolon in ethanol extract, of P. merrillii (PM) was done by Chang et $\mathrm{al}^{7}$. They described the fingerprint chromatogram of PM and hispolon standard. Both PM and hispolon showed similar peak at the retention time of $4.70 \mathrm{~min}$. In addition, liquid chromatography-tandem mass chromatography (LC-MS/MS) showed that both PM and hispolon standard had similar daughter ions at $\mathrm{m} / \mathrm{z}$ 219 and 135, respectively. The result indicated that PM did contain the active ingredient of hispolon. Chang et $\mathrm{al}^{8}$ also used HPLC for hispolon analysis in ethanol extract of PM by changing the mobile phase from methanol:water at 70:30 (v/v) that they previously did into acetonitrile:water at 50:50 (v/v). The result showed that the fingerprint chromatogram of both hispolon and PM had a similar peak at the retention time of $6.00 \mathrm{~min}$. Jung et $\mathrm{al}^{9}$ determined antioxidant fractions of ethyl acetate extract of the culture broths obtained from PL using reversed-phase HPLC. The substances found in the culture broths of PL were hispidin and its dimers rather than hispolon. Samchai et al ${ }^{10}$ studied antioxidant activities of PL collected from Thailand. They extracted PL powder with different solvents: water, ethanol, $50 \%$ ethanol, 80\% ethanol, and ethyl acetate, under two conditions: heated at $60^{\circ} \mathrm{C}$ and at room temperature in a small scale extraction. In addition, a large scale extraction was also studied using methanol as a solvent for PL powder extraction. The antioxidant activity of 11 crude extracts were further determined with the DPPH method. The results showed that the antioxidant activity of crude extracts from heated extraction exhibited stronger activity than that extracted at room temperature for all kind of solvents in a small scale extraction. Both crude, 50\% ethanol, and 80\% ethanol extracts showed higher antioxidant activity than water, ethanol, and ethyl acetate extract in both conditions of small scale extraction. For a large scale extraction, crude methanol extract showed a slightly lower antioxidant activity than crude $50 \%$, or $80 \%$ ethanol extract. The results of Samchai et al indicated that phenolic compounds conferring an antioxidant activity to PL were polar compounds. These com- pounds dissolved well in polar organic and alcoholaqueous solvents. As the hispolon content of Thai PL is unknown, this work aims to determine hispolon content by HPLC-UV and to confirm its presence in Thai PL (or krathin phiman) by LC-MS/MS with daughter ion scanned mode.

\section{MATERIALS AND METHODS}

\section{Sample preparation}

Fresh fruiting bodies of Thai PL were obtained from a folk medicine company in the northern region of Thailand. The mushrooms were dried at room temperature and ground by grinder (Moulinex, type NE401, France) to make powder (40-60 mesh) for further hispolon extraction. Hispolon standard was purchased from Enzo life sciences (Farmingdale, New York). The purity of hispolon standard was higher than $98 \%$ by HPLC.

\section{Extraction and determination of hispolon content}

Hispolon was extracted from $5 \mathrm{~g}$ of dried mushroom powder using $200 \mathrm{ml}$ of $50 \%, 80 \%$, and $95 \%$ ethanol as solvent in a soxhlet extractor (Buchi, Switzerland) for $6 \mathrm{~h}$. After extraction, ethanol was further evaporated by a vacuum rota-evaporator until $10 \mathrm{ml}$ of solution was obtained. Hispolon concentration was determined as described in Ref. 7. An aliquot was loaded on an HPLC-UV reverse phase (cosmosil C18AR-II, $5 \mu \mathrm{m}(150 \mathrm{~mm} \times 4.6 \mathrm{~mm}$ ID) from water $)$ column. The separation was performed at $35^{\circ} \mathrm{C}$ and the flow rate was $0.5 \mathrm{ml} / \mathrm{min}$ using isocratic elution of $1: 1(\mathrm{v} / \mathrm{v})$ deionized water mixed with acetonitrile as a mobile phase. The hispolon peak was detected at $300 \mathrm{~nm}$ and appeared at $6.50 \mathrm{~min}$ of chromatogram. The results were expressed as equivalent to an external standard, hispolon.

\section{Confirmation of hispolon by LC-MS/MS}

Analyses were also carried out by the negative mode API-electrospray ionization of LC-MS/MS analysis. Chromatographic separation of hispolon was performed on $\mathrm{C} 18$ water Atlantis $(5 \mu \mathrm{m}, 2.7 \times 50 \mathrm{~mm})$ column under as isocratic elution of a mixed solvent system of $70 \%$ of methanol and $30 \%$ of water at a flow rate of $0.5 \mathrm{ml} / \mathrm{min}$. A full UV spectrum was scanned from $200-400 \mathrm{~nm}$. The source and desolvation temperatures were set at 120 and $350^{\circ} \mathrm{C}$, respectively. All processes were set as follows: the capillary voltage $3 \mathrm{kV}$, cone gas flow 50-60 1/h, desolvation gas flow 500-600 $\mathrm{l} / \mathrm{h}$, and collision energy $15 \mathrm{eV}$ for hispolon $[\mathrm{M}-\mathrm{H}]^{-}$fragment $(m / z=218.9)$ daughter ion scan. The two daughter ion spectra obtained from hispolon standard and Thai PL extract were compared. 


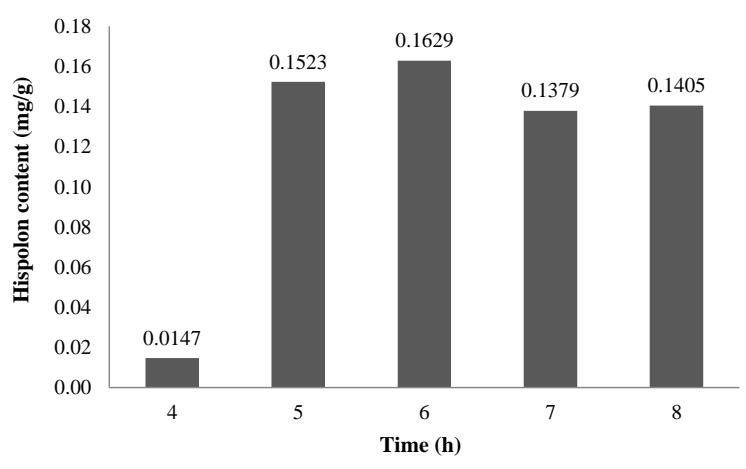

Fig. 3 The content of hispolon in dried powder of Thai PL prepared under various extraction times.

\section{RESULTS AND DISCUSSION}

Selection of a suitable solvent is the most important step in optimizing the recovery of a desired compound from a complex matrix. Many factors such as solvent characteristic, extraction time, temperature, and ratio of sample to solvent have an influence on extraction ${ }^{11}$. In this experiment, we selected ethanol as a solvent followed the work of Chen et al ${ }^{8}$ because the crude extract of PL contains effective component in an anti-cancer test. Our extraction results showed that the hispolon contents at $4 \mathrm{~h}$ of extraction time with $50 \%, 80 \%$, and $95 \%$ ethanol were $0.0000 \mathrm{mg} / \mathrm{g}$, $0.0025 \mathrm{mg} / \mathrm{g}$, and $0.0147 \mathrm{mg} / \mathrm{g}$ of dried mushroom powder, respectively. The result revealed that $95 \%$ ethanol can promote the extraction with the highest content of hispolon. The result showed that the recovery of hispolon was clearly increased by decreasing polarity of the solvent $(50 \%>80 \%>95 \%)$. Thus $95 \%$ ethanol was chosen as the solvent for further extraction of Thai PL powder for various extraction times. Five extraction times were compared and the yields of hispolon are shown in Fig. 3.

Increasing the extraction time between 4 and $6 \mathrm{~h}$ resulted in an increase of the hispolon content (Fig. 3). After the highest point was reached at $6 \mathrm{~h}$, the hispolon content started to decrease again between 7 and $8 \mathrm{~h}$. This could be attributed to the extraction state of the dried mushroom powder, i.e. moisture content for instance. The presence of bounded moisture, due to inefficient drying in the mushroom powder samples, reduced the solvent extraction efficiency resulting in low hispolon recovery ${ }^{12}$. Since the highest hispolon content of $0.1629 \mathrm{mg} / \mathrm{g}$ dried mushroom powder was obtained at $6 \mathrm{~h}$ of extraction time, this time was selected for our dried mushroom powder extraction.

The results of authentic hispolon compound and the composition of crude Thai PL analysis by HPLC-
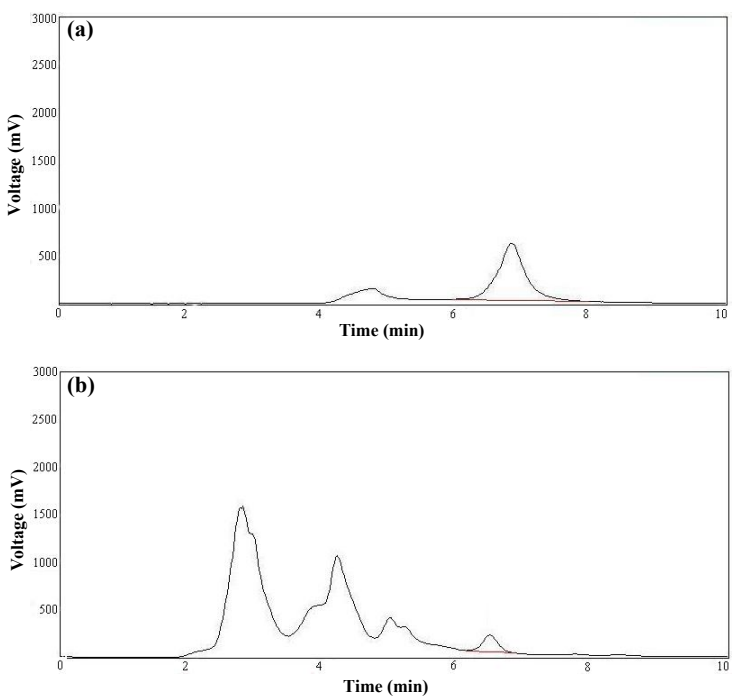

Fig. 4 HPLC chromatogram of hispolon: (a) standard PL, and (b) Thai PL extract.

UV are shown in Fig. 4. Both hispolon standard and crude Thai PL extract showed similar peak at peak base started from 6.2 min (crude Thai PL peak 6.2$6.6 \mathrm{~min}$, standard hispolon peak 6.2-7.2 min). The chromatogram indicated that Thai PL did contain the active ingredient hispolon because the peak of crude Thai PL overlapped with that of the hispolon standard.

To confirm the presence of hispolon in Thai PL crude extract, the solution eluted from HPLC between 6.2 and 6.6 min was collected and further analysed by LC-MS/MS. The experiment was conducted in triplicate. The confirmation of hispolon by LC-MS/MS with daughter ion scanned mode of both hispolon standard and hispolon collected from crude Thai PL extracted showed two daughter ion spectra (Fig. 5). Both hispolon standard and crude Thai PL extract had the same parent ion at $m / z 218.91$ and similar daughter ion at $m / z 176,160$, and 135 , respectively. The fragmentation results (Fig. 5) was similar to the fragmentation described by Chang et $\mathrm{al}^{7}$, who used LC-MS/MS to confirm hispolon in P. merrillii extracts.

The confirmation result by LC-MS/MS strongly suggested that the peak at 6.2-6.6 min of crude Thai PL was the hispolon compound. In addition, hispolon combined with hispidin to yield hispolon dimers and its dimers rearrangement compounds were found in Korean PL using on-line HPLC-DPPH and the active compound was identified by LC-MS and NMR method ${ }^{13}$. Hispidin dimers such as hispidin with hispolon or hispidin with hispidin were reported 

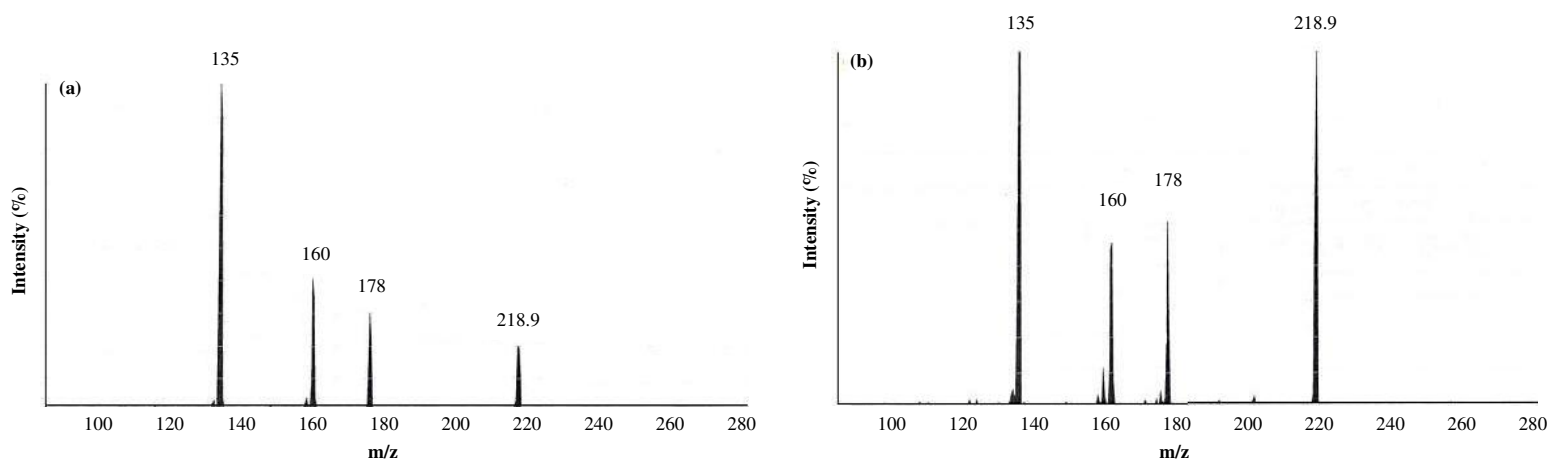

Fig. 5 The composition of daughter ion scanned chromatogram of hispolon: (a) standard PL, and (b) Thai PL extract.

to have a strong antioxidant capacity. Their results, therefore, support the presence of hispolon compound in PL, the same as our discovery.

\section{CONCLUSIONS}

Our results are the first report in Thailand in which advanced instrumental analysis (HPLC-UV and LCMS/MS) were used to determine and confirm hispolon content in Thai PL for traditional medicine. The results disclosed that the extraction with $95 \%$ ethanol for $6 \mathrm{~h}$ was promising for hispolon extraction by soxhlet extraction. In addition, the achievement of hispolon confirmation in Thai PL ensures that Thai PL has a potential for anti-cancer, the same as PL mushroom from Taiwan, China, or Korea. Currently, a pilot plant of hispolon extraction from Thai PL using the obtained optimum condition is being investigated.

Acknowledgements: This study was supported by the higher Education Research Promotion and National Research University Project of Thailand, Office of the higher Education Commission. We also thank the Centre of Excellence-Oil Palm, Kasetsart University, for partial support.

\section{REFERENCES}

1. Kang SA, Park HJ, Kim MJ, Lee SY, Han SW, Leem KH (2005) Citri Reticulatae Viride Pericarpium extract induced apoptosis in SNU-C4, human colon cancer cells. J Ethnopharmacol 97, 231-5.

2. Park SE, Kim J, Lee YW, Yoo HS, Cho CK (2009) Antitumor activity of water extracts from Cordyceps militaris in NCI-H460 cell xenografted nude mice. J Acupunct Meridian Stud 2, 294-300.

3. Huang GJ, Deng JS, Chiu CS, Liao JC, Hsieh WT, Sheu MJ, Wu CH (2012) Hispolon protects against acute liver damage in the rat by inhibiting lipid peroxidation, proinflammatory cytokine, and oxidative stress and downregulating the expressions of iNOS, COX-2, and MMP-9. Evid Based Complement Alternat Med 2012, Article ID 480714, doi: 10.1155/2012/480714.
4. Ali NAA, Jansen R, Pilgrim H, Liberra K, Lindequist U (1996) Hispolon, a yellow pigment from Inonotus hispidus. Phytochemistry 41, 927-9.

5. Mo S, Wang S, Zhou G, Yang Y, Li Y, Chen X, Shi J (2004) Phelligridins C-F: cytotoxic pyrano[4,3-c] [2] benzopyran-1,6-dione and furo[3,2-c]pyran-4-one derivatives from the fungus Phellinus igniarius. $J$ Nat Prod 67, 823-8.

6. Chen W, He FY, Li YQ (2006) The apoptosis effect of hispolon from Phellinus linteus (Berkeley \& Curtis) Teng on human epidermoid KB cells. J Ethnopharmacol 105, 280-5.

7. Chang HY, Ho YL, Sheu MJ, Lin YH, Tseng MC, Wu SH, Huang GJ, Chang YS (2007) Antioxidant and free radical scavenging activities of Phellinus merrillii extracts. Bot Stud 48, 407-17.

8. Chang HY, Peng WH, Sheu MJ, Huang GJ, Tseng MC, Lai MT, Ho YL, Chang YS (2007) Hepatoprotective and antioxidant effects of ethanol extract from Phellinus merrillii on carbon tetrachloride-induced liver damage. Am J Chin Med 35, 793-804.

9. Jung JY, Lee IK, Seok SJ, Lee HJ, Kim YH, Yun BS (2008) Antioxidant polyphenols from the mycelial culture of the medicinal fungi Inonotus xeranticus and Phellinus linteus. J Appl Microbiol 104, 1824-32.

10. Samchai S, Seephonkai P, Sangdee A, Puntumchai A, Klinhom U (2009) Antioxidant, cytotoxic and antimalarial activities from crude extracts of mushroom Phellinus linteus. J Biol Sci 9, 778-83.

11. Huie CW (2000) A review of modern sample-preparation techniques for the extraction and analysis of medicinal plants. Anal Bioanal Chem 373, 23-30.

12. Hamamre ZA, Foerster S, Hartmann F, Kroger M, Kaltschmitt M (2012) Oil extracted from spent coffee grounds as a renewable source for fatty acid methyl ester manufacturing. Fuel 96, 70-6.

13. Jeon YE, Lee YS, Lim SS, Kim SJ, Jung SH, Bae YS, Yi JS, Kung IIJ (2009) Evaluation of the antioxidant activity of the fruiting body of Pheillinus linteus using the on-line HPLC-DPPH method. J Kor Soc Appl Biol Chem 52, 472-9. 